\title{
Impact of Transformational Leadership on Employees' Performance in Expor-based Small Medium Entreprises
}

\author{
${ }^{1}$ Widiartanto*, ${ }^{2}$ Wiwiek Harwiki \\ 1Diponegoro University Semarang, Indonesia \\ ${ }^{2}$ Dr. Soetomo University Surabaya, Indonesia \\ *fafanabil@gmail.com
}

\begin{abstract}
The study is aimed at examining the effect of transformational leadership on employee performance through employee empowerment and organizational commitment as a mediating variables of the cluster of carving copper in Cepogo Boyolali. The research samples cover 30 employees of the CV. Intermedia Logam as part of a cluster of carving copper. Sample determination applies totals sampling or population sampling in which all members of the population are used as research samples. In examining the established model relationship, the data are analyzed by using path analysis. The results revealed: transformational leadership gives positive and significant effect on employee empowerment; transformational leadership gives positive and significant effect on employee performance; employee empowerment gives positive and significant effect on employee performance; organizational commitment as a mediating variables between transformational leadership and employee performance, employee empowerment as a mediating variables between transformational leadership and employee performance, and organizational commitment as a mediating variables between employee empowerment and employee performance. This research suggests that companies disseminate the vision, mission and goals; conduct of training; and providing incentives to the agreement in order to achieve employment targets.
\end{abstract}

Keywords: Transformational Leadership, Employee Empowerment, Organizational Commitment, Employee Performance

\section{Introduction}

The paradigm of competition that used to be a material or physical asset has shifted to knowledge-based competition (Tuomi, 1999). Hence, it requires both efficiency and effectiveness in the use of human resources as the foundation for organization in order to be able to compete and have a competitive advantage. The utilization of human resources as the basic capital must be followed by the development and renewal of the workers' capabilities and expertise so that every member of the organization is able to respond and be susceptible towards any changes, and therefore, every member of the organization supports the organization renewal (Khan, 2004). Thus, an organization requires continuous cooperation from various resources to grow bigger, stronger, firmer and more resilient to face any challenges and to win the competition. To ensure cooperation, a leader who can provide knowledge, expertise and capabilities in managing human resources is needed. Here, each section understands its duties and responsibilities to support one another and provide the best contribution for the organization. In a complex and ever changing business environment, it currently needs a leader who is able to anticipate the future and have relevant policies in today's complex situation. The essence of leadership is facilitating individual development to realize his potential (Haryanto, 2002).

There are various strategies that can be applied by organizations to develop and renew the capabilities and expertise of employees in facing more complex organizational problems. At this point, empowerment is one of the many ways in developing employees through employee involvement; that is, giving enough authority and responsibility to complete the task and to make decision (Chaudron, 2005). A leader has a strategic role as an agent of change in the process of empowerment since it involves the process of distribution of power (Khan, 2004). Therefore, a leader is required to have awareness towards the distribution of power and authority as part of the process of regeneration and continuous human resources upgrading to achieve optimal productivity and performance. The effectiveness and success of an organization are determined by 
the quality of the leader in leading the organization and the quality of the employees as members of the organization. Employees must find it interesting and have the sense of belonging so that they maintain their presence in an organization. The sense of belonging towards an organization will encourage employees to perform his/her job well; even they are also willing to do work or duties outside his/her responsibilities for the sake of the sustainability of the organization.

Transformational leadership is a concept that is able to answer this challenge. Based on this concept, the duty of a leader is to motivate his/her subordinates to perform the work beyond their expectations and previous estimation. Transformational leaders are trying to raise subordinates' awareness by encouraging idealism and higher moral values, such as, freedom, justice, peace, balance, and humanity which are not based on emotional feeling such as fear, greed, jealousy and hatred (Burns in Yukl, 2009). As human beings, subordinates also have to fulfill their needs. Fulfilling the needs of subordinates will be beneficial to both the subordinates and the organization. Organization demands the willingness of its subordinates to succeed the objectives of the organization; meanwhile, the subordinates need a pleasant job, an opportunity to participate, adequate wages, an opportunity to be promoted, and a good relationship between superiors and subordinates. Steers and Porter (in Purwanto \& Adisubroto, 2001) argued when the agreement between both parties can be performed fairly, it eventually fosters a high commitment of the subordinates towards the organization which stimulates the subordinates to work well and to be able to compete in tight and competitive conditions.

Organizational commitment can be interpreted as the relative strength of a person's identification and involvement in a particular organization (Mowday, 1979 in Yukl, 2009). The existence of employees with high commitment to the organization will lead the organization to a favorable condition. Such employees will compete with one another to help the organization by working more effectively in normal situation and will actively maintain the organization when unfavorable condition exists (Dessler, 2006). Employees with high commitment are likely to act in accordance with the values and norms existing in the organization, hence, deviation and disobedience can be prevented. Besides, such organizations with high committed employees will acquire higher efficiency and will not require a lot of supervision. On the other hand, such organizations having employees with low commitment will reduce the effectiveness of the organization (Gibson, 1978 in Purwanto \& Adisubroto, 2001). Employee commitment to the organization is necessary since high commitment is correlated with low employee's turn over having moved to another job, absenteeism level, and the slowness of work can be reduced. In fact, it increases job satisfaction and higher awareness of the employees towards the existence and success of the organization. Organization needs employees willing to do anything exceeding their duties and work, even sacrificing themselves for the success and sustainability of the organization (Borman \& Motowildo in Muchiri, 2002)

In addition, the commitment of an organization arises in an atmosphere providing opportunity for the employees to participate, and it can be created by the hands of the leaders. Pfefer (1996 in Khan, 2004) states the entanglement can only be created and maintained through participation. When people are involved in their humans side, the desire to participate is increasing, or in other word, participation increases engagement and engagement forms a commitment. Transformational leadership provides support, encouragement, and developing experiences to its followers (Yukl, 2009). It means they provide broad opportunities to its followers in order to exploit and develop their potentials. Every employee participating and involving actively with the company will strive to create and manifest his/her abilities in order to be in line with the objectives of the organization. Hence, the Transformational leadership is considered capable of forming the commitment of the employee. The export-based SME sector is considered as the industry having competitive spirit of which its products serve the international market performed by individuals or traders/mediator (RI-PIKM, 2002-2004). Issues on leadership style, the empowerment of the employee, organizational commitment and the performance of the employee are interesting issues to discuss. The export-based SME sectors have several characteristics; among others, sufficient competitiveness, domestic natural resource based, labor intensive, providing opportunities to work and vast market opportunities. For the SME of cooper carving crafts in Boyolali regency, the development on human resources covers improving design, capacity building in export-import and negotiation techniques and improving expertise in product quality. Creativity and innovation are considered as the determining factor of their products. The objectives 
of the study is to find out the effect of transformational leadership on employee empowerment, organizational commitment, employee performance as well as to determine the mediating variables on the effect of transformational leadership on employee performance and the effect of employee empowerment on employee performance in small-medium enterprise of cooper carving center.

\section{Literature Review}

Leadership is a person's process in leading, guiding, influencing mind or thought, feeling and other person's behavior to achieve certain goal. In general, leadership is defined as the activity to influence a group of people towards the achievement of goals (Robbins, 1996). Meanwhile, Thoha (1995) argues that leadership is the activity to influence the behavior of others or the art of influencing human behavior, both individual and groups. Burns in Yukl (2009) defines transformational leadership as a process of raising the morale and motivation of leaders and subordinates to a higher level. Here, transformational leaders are trying to raise the awareness of the subordinates by encouraging higher idealism and moral values, such as, freedom, justice, peace, balance, humanity that are not based on emotional feeling such as fear, greed, jealousy and hatred. Bass in Yukl (2009) proposes a theory of transformational leadership based on the earlier ideas of Burns in Yukl (2009). The degree to which a leader is considered as transformational is mainly measured in the relation between the leader and his/her effect towards the followers. The followers of a transformational leader feel the presence of trust, admiration, loyalty and respect in the characteristics of the leader. They are even motivated to do more than what the leader initially expected them to do. There are various definitions on the word empowerment proposed by theorists. According to Chaudron (2005), empowerment is an assignment of responsibilities and authority to the workers in making decision regarding the development of products and decision making. Meanwhile, Khan (2004) states that empowerment is a continuous interpersonal relationship to establish trust between employees and the management. Further, Byars \& Rue in Handoko \& Tjiptono (2000) explain empowerment as a form of decentralization involving the assignment of responsibilities to the subordinates in decision-making process.

From the above definitions, there are some important points on the notion of what an empowerment is, namely: First, the assignment of responsibilities and authority to the employees. Second, empowering the agent of change since the distribution of power occurs in the empowerment process. Third, the existence of employee involvement in the process that involves employees in decision-making. Organizational commitment is often defined as: (1) a strong desire to remain a member of the organization; (2) the willingness to use all skills/efforts on behalf of the organization interests; (3) trust, the acceptance of values and goals of the organization. In other words, organizational commitment is an attitude reflecting the loyalty of employees to the organization and a continuous process in which members of the organization express their concern at the sustainable success and the life of the organization (Luthans, 1998). Dessler (2006) explains one of the definitions related to employee performance. According to Dessler, performance is the result of the work accomplished by a person or group of people within an organization in a certain period based on the authority and responsibilities of each member as an effort to achieve the goals of the organization legally in accordance with the law, moral and ethics. There are various strategies that can be applied by organizations to develop and renew the capabilities and expertise of employees in facing more complex organizational problems. Empowerment is one of the ways in developing employees through employee involvement; giving sufficient authority and responsibilities to complete the job and to make decision (Chaudron, 2005). The leader has a strategic role in the empowerment process as the agent of change since the distribution of power occurs in the empowerment process. (Khan, 2004). Therefore, a leader is required to have awareness towards the distribution of power and authority as the process of regeneration and enhancement of sustainable capabilities of the human resources in order to achieve optimal productivity and performance.

Commitment to the organization is influenced by many factors one of which is leadership factor that is considered as the influential factor in forming a commitment (Yukl, 2009). The growth of the subordinates commitment is related to whether the needs of the subordinates are fulfilled or not (Pfefer, dalam Yukl, 2009). It is commonly known that human beings have five kinds of needs. Those five needs, according to Maslow, are placed in a hierarchy starting from the lowest need to the highest need. The needs of the 
subordinates can be fulfilled by applying transformational and transactional leadership style. Bycio et al. (1995) argues that the lower need of the subordinates such as physical needs, security and affiliation can all be fulfilled by applying transactional leadership style. It is basically an exchange process between superiors and subordinates over previous agreement. On the other hand, the higher need of the subordinates such as self-esteem and self-actualization can be fulfilled, according to Keller (1992), through the practice of transformational leadership. The fulfillment of the higher needs will have an impact on increasing commitment (Bass in Yukl, 2009). The fulfillment of the needs of employees actually reflects the success of empowerment conducted by an organization. Employees who have experienced the feeling of being "powerful" will have higher commitment comparing to those who still feel "powerless".

Several of the previous studies relevant to the issues in this research include the study of Bycio et al. (1995) entitled "Further Assesment of Bass's (1985) Conceptualization of Transactional and Transformational Leadership" and it has been published in the Journal of Applied Psychology using Multifactor Leadership Questionaire with the samples of members of nurses association. This study related to the transactional and transformational leadership style with effectiveness, performance and satisfaction towards the leader and the commitment to the organization. Five variables are used in this research and three of them are considered as transformational leadership variable-charismatic leadership, individualized consideration and intellectual stimulation. Meanwhile, the other two variables are considered as transactional leadership stylecontingent reward and management by exception. The analysis applies correlation and multiple regression. The result shows high correlation between the study variables. The study also shows a strong and positive relationship between the variables of transformational leadership and the effectiveness, performance, satisfaction towards the leader and commitment to organization, as well as contingent reward variable. However, management by exception variable shows negative relationship and charismatic leadership is a variable having the dominant influence.

The next research is the study of Keller (1992) entitled "Transformational Leadership and the Performance of Research and Development Project Groups" and it has been published in the Journal of Management. The study is aimed at finding out the influence of transformational leadership style towards the performance of employees in several projects. The samples involve 342 respondents consisting of employees working in the project. The respondents are asked to assess the leadership style shown by the manager of the project. Statistical analysis uses path analysis and it is found that overall transformational leadership style variables have positive influence and are considered significant to the performance of the employees. The study of Schappe (2011) entitled "The Influence of Job Satisfaction, Organizational Commitment, and Fairness Perception on Organizational Citizenship Behavior" and it has been published in the Journal of Psychology. The study is aimed at finding the effect of job satisfaction, employee commitment towards organization and the perception of fairness to the behavior of the members of organization. The samples involve 130 employees of an insurance company in the Atlantic. The result of the regression analysis shows that the three independent variables are tested together and it reveals only employee commitment variable to the organization that has the lowest correlation to the behavior of the organization members.

Another research is conducted by Purwanto \& Adisubroto (2001) entitled "The Relationship between Transformational and Transactional Leadership Style with Commitment to Organization". It has been published in the Jurnal Sosiohumanika. The study is aimed at applying the relationship between transformational and transactional leadership style towards organizational commitment. The research subjects are female nurses at Dr. Sardjito Hospital and Bethesda Hospital who have worked for at least one year. A number of 202 subjects are randomly determined. Data are collected by using two questionnairesMultifactor Leadership Questionnaire (MLQ) to obtain data on leadership and Commitment Questionaire to data on the level of commitment to organization. Data analysis applies partial correlation analysis and multiple regression. The result shows positive and significant relationship between transformational and transactional leadership style and the organizational commitment. The study of Muchiri (2002) entitled "The Effect of Leadership Style on Organizational Citizenship Behavior and Commitment" has been published in Gadjah Mada International Journal of Business. It is aimed at finding the effect of transformational and transactional leadership style of the supervisor towards the behavior of the members of organization and the commitment of the subordinates at the Railway Company Indonesia. The subjects of the research are all male 
workers and are randomly chosen by using purposive random sampling method. The analysis of regression and correlation shows transformational and transactional leadership style has significant effect towards the behavioral variables of the members and commitment to organization.

The research of Khan (2004), entitled "The Key to Being a Leader Company: Empowerment" is published in the Journal of Personality and Participation and is aimed at determining the effect of leadership on empowerment and organizational performance in several manufacturing companies in the United States of America. The empowerment process steps described in the model uses several stages, among others desire, trust, confident, credibility, accountability and communication. The results of the path analysis show that leadership has significant ands positive effect on the empowerment and organizational performance. The empowerment variable strengthens the effect of leadership on the performance of the organization, or in other words, empowerment variables are used as mediating variables. The latter is a research conducted by Chaudron (2005) entitled "Creating an Empowering Environment". It has been published in the Personal Journal. The study is aimed at determining the effect and relation of empowerment to business performance. Statistical analysis is used with multiple linear regression and product moment correlation. The result shows that there is a significant and positive effect of the empowerment to business performance. Based on the above concepts of transformational leadership style, employee empowerment, organizational commitment and performance of employees, the framework used in this study can be described in Figure 1 as follows:

Figure 1: Conceptual Framework

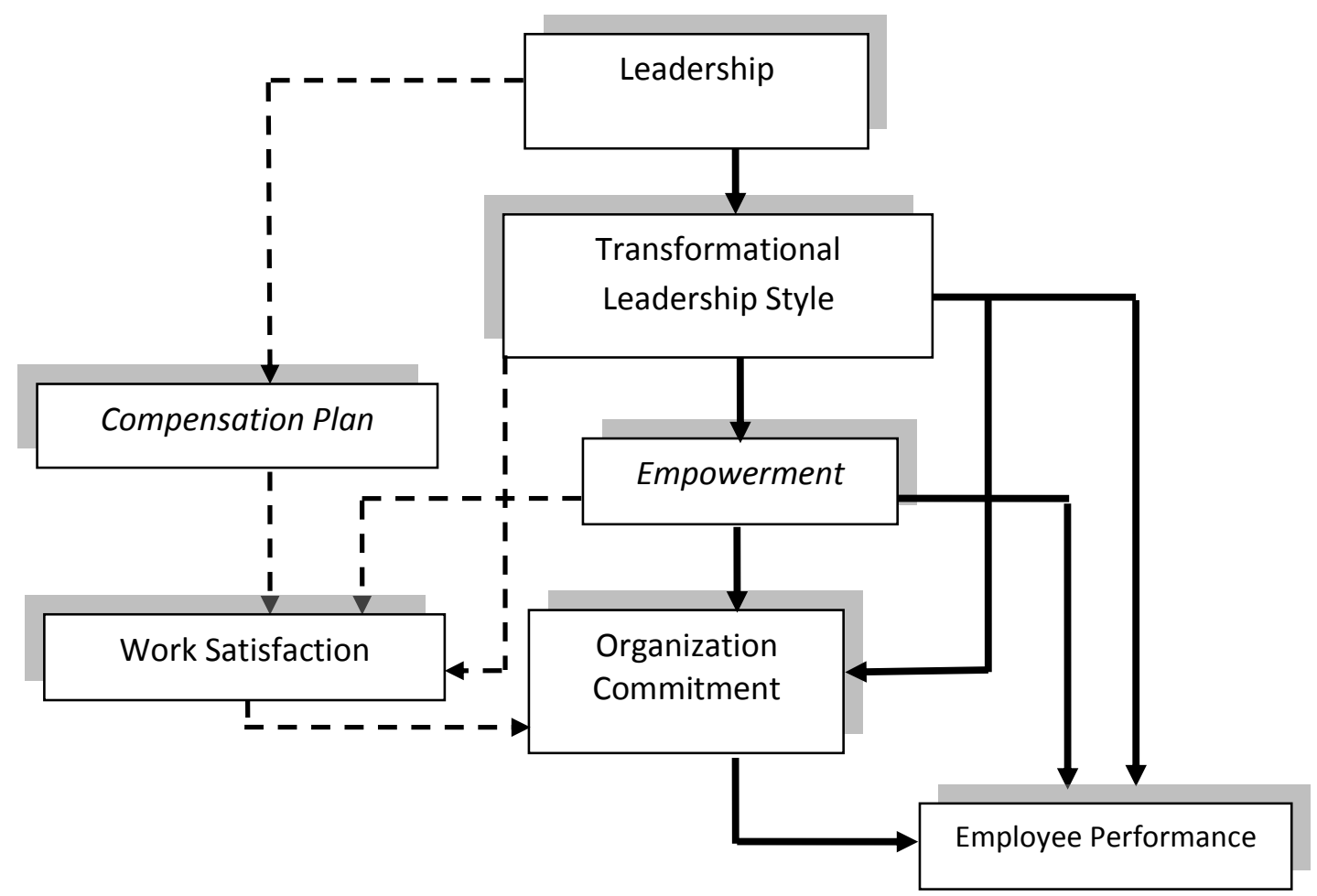

$\boldsymbol{-}-\boldsymbol{-}=$ not examined

to be examined

Source: proceesed by authors

The Model for this study based on the conceptual framework on Figure 1 as follow: 
Figure 2: Research Model

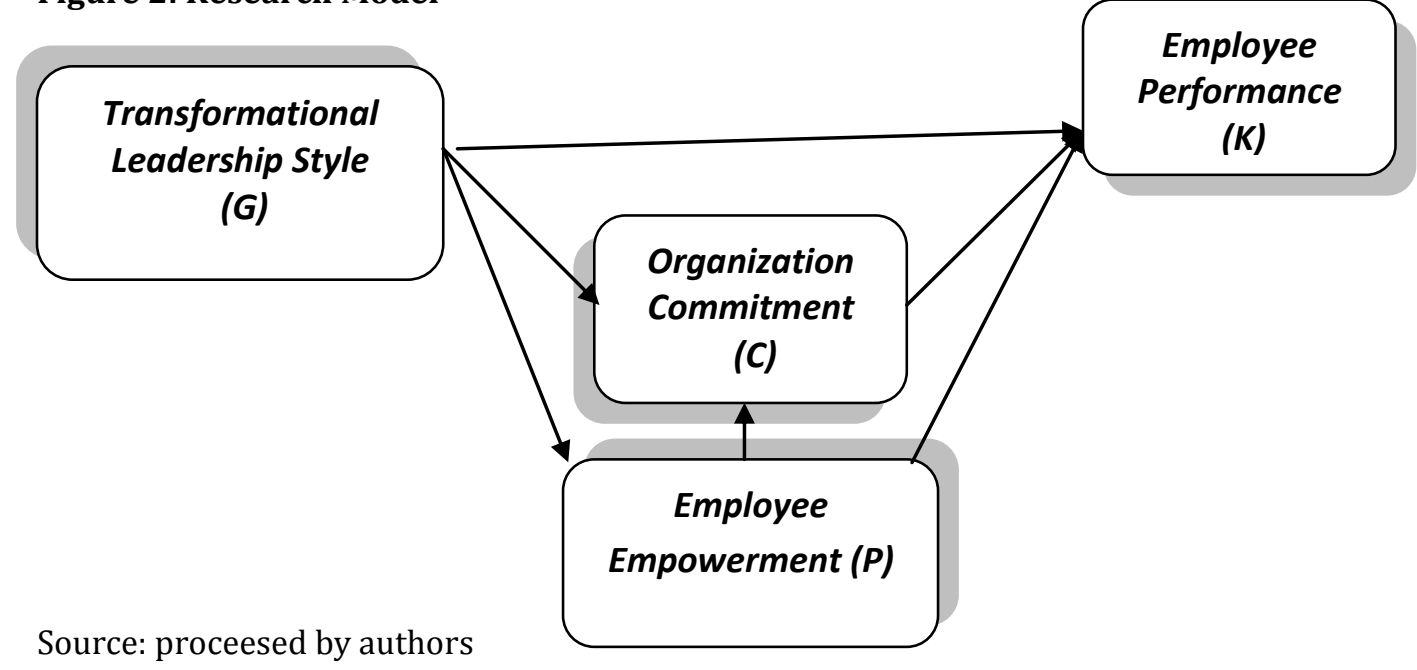

\section{Methodology}

The method of research applies survey method with the research type of explanatory research. The location of research is at the CV. Intermedia Logam in Tumang Kradjan village RT 04 / RW 14 Cepogo, District of Boyolali as part of the cooper craft clusters. The population in this study are the workers / employees at CV. Intermedia Logam with the total of 30 workers. All employees are used as samples of population, so the technique of collecting samples applies census or total sampling. Measurement of scale uses Likert scale. Techniques of data collection use documentation method, questionnaires, interviews, and library research method. Data analysis technique applies qualitative and quantitative analysis. The instrument used in the data analysis is path analysis.

\section{Results}

All respondents are male (100\%) with the majority of respondents are in the age of 31-35 that is equal to $36.6 \%$. The majority of respondents are married with the percentage number of $73.3 \%$. The majority of respondents are primary school graduates that is equal to $53.3 \%$ with the dependents of $1-2$ persons. The majority of respondents has worked for $>4$ years with the level of income per month at 500,000 Rupiah to 750,000 Rupiah. Mean variable of transformational leadership style is equal to 3.72, which means that the variable of transformational leadership style is in good condition. Mean variable of employee empowerment is at 3:27, which means that the variable of employee empowerment is in good condition. Mean variable of employee commitment is equal to 3.73, which means that the variable of employee commitment is in good condition. Mean employee performance variable is 3.10, which means that the variable performance of the employees is in good condition. All of question items are valid and reliable. It is reflected in all grades of corrected item total correlation ( $r$ value results) in which all question items are greater than the value of $r$ table (0.349), as well as all the alpha value of each variable that is greater than 0.60 . Results of regression analysis to determine the effect of transformational leadership style among the variables (G), empowerment of employees (P), organizational commitment (C) and employee performance (K), either directly or through mediating variables, have shown the following data 
Table 1: Recapitulation of Influences Inter Variables Directly

\begin{tabular}{lllllll}
\hline Relationship & Constanta & $\begin{array}{l}\text { Regression } \\
\text { Coefficient }\end{array}$ & Sig.t & $\begin{array}{l}\text { Correlation } \\
\text { Coefficient }\end{array}$ & $\begin{array}{l}\text { Determitation } \\
\text { Coefficient }\end{array}$ & Decision to Ho \\
\hline G - K & 8.439 & 0.105 & .029 & 0.400 & 0.160 & Rejected \\
G - P & -7.570 & 0.942 & .000 & 0.659 & 0.434 & Rejected \\
P - K & 11.461 & 0.0727 & .031 & 0.395 & 0.156 & Rejected \\
P - C & 35.187 & 0.239 & .024 & 0.412 & 0.169 & Rejected \\
G - C & 11.685 & 0.549 & .000 & 0.661 & 0.437 & Rejected \\
C- K & 7.647 & 0.162 & .004 & 0.511 & 0.261 & Rejected \\
\hline
\end{tabular}

Table 2: Recapitulation of Influences Inter Variables through Intermediary Variables

\begin{tabular}{lll}
\hline Relationship & $\begin{array}{l}\text { Correlation } \\
\text { Coefficient }\end{array}$ & Comments \\
\hline G-C-K & $\mathrm{r}_{\mathrm{GC}}=0.437$ & Commitment organization variable as the intermediary variable \\
& $\mathrm{r}_{\mathrm{CK}}=0.511$ & bridging relations of transformational leadership style and \\
& $\mathrm{r}_{\mathrm{GK}}=0.400$ & employee performance. \\
P-C-K & $\mathrm{r}_{\mathrm{PC}}=0.412$ & Commitment organization variable as the intermediary variable \\
& $\mathrm{r}_{\mathrm{CK}}=0.511$ & bridging relations employee empowerment and employee \\
& $\mathrm{r}_{\mathrm{PK}}=0.395$ & performance. \\
G-P-K & $\mathrm{r}_{\mathrm{G}}=0.659$ & Employee empowerement variable as the intermediary variable \\
& $\mathrm{r}_{\mathrm{PK}}=0.395$ & bridging relations of transformational leadership and employee \\
& $\mathrm{r}_{\mathrm{GK}}=0.400$ & performance \\
\hline
\end{tabular}

Discussion: In principle, this study is aimed on analyzing the influence between the variables in the research model, namely the effect of transformational leadership style variable, employee empowerment, and organizational commitment to employee performance. Other objectives are to identify the mediating variables of organizational commitment and employee empowerment that affect the style of transformational leadership on employee performance. The results of this study are empirically in line with the research of Bycio, Allen \& Hackett (1995) who conclude that there is a strong and positive relationship between transformational leadership style variables on organizational commitment and employee performance. Some relationships between variables in this study are also empirically in line with the research of Keller (1992), Purwanto and Adisubroto (2001), Muchiri (2002), Khan (2004), and Chaudron (2005). Keller (2992) concluded that overall the variables of transformational leadership style have positive and significant impact on employee performance. The result of Purwanto\&Adisubroto (2001) research also concludes that there is a positive and highly significant relation between transformational leadership style and organizational commitment. Multifactors Leadership Questionnaire (MLQ) and Commitment Questionnaire in the research of Purwanto and Adisubroto is used and adopted in this study in order to obtain data on transformational leadership and the level of commitment to the organization.

Muchiri also has the same conclusion. There is significant relationship between transformational leadership style and organizational commitment. Meanwhile, Khan (2004) concluded that the leadership variable has positive and significant effect on the empowerment and organizational performance and identifying variables as mediating variables. The result of Chaudron's (2005) research strengthens Khan's study that there is a relationship and a positive and significant effect between empowerment and business performance. Overall, the results of this study confirms that the concept of transformational leadership has the essence of sharing of power involving subordinates to make changes. By applying various managerial practices, leaders with transformational style are able to empower subordinates, in other words, they can significantly strengthen the confidence of the subordinates concerning their ability. With more powerful sense of self-efficacy, the employee will be able to work and succeed in a variety of challenging tasks. Many new leadership studies reveal that the practice of empowerment or creating a sense of power is the root of organizational effectiveness, especially in transition and transformation era. Today the concept of empowerment has appeared to be one of the new views to improve employee motivation and productivity. Through this concept, 
employees are entrusted with bigger authority and responsibility in decision making. Here, communication or exchange of information and knowledge between managers and employees is required so that the employees can truly understand their duties and can make a real contribution to the achievement of the organization. Empowerment is different from participatory approaches in the past, which tend to only emphasize the collection of input / feedback from employees, but never uses it and / or is never accompanied with the delegation of authority.

Empowerment aspect is actually not absolute, but it is rather "a matter of degree". That is, the level of empowerment for individuals and teams doest not have to be in equal portions or levels. Even for a certain individual tasks or responsibilities in different field of decision (decision areas) can apply different levels of empowerment. Selection of the applied empowerment strategies can be done by considering two dimensions, namely job content and job context (Ford \& Fottler, 1995 in Yukl, 2009). Job content describes processes and tasks required to perform a specific job. While the job context illustrates the correspondence between the work and the mission, goals, and objectives of the organization as a whole and the organizational setting in which the work is performed. It is recognized that this study has some limitations, though the utilization of the existing resources has already done optimally. The limitations are as follows: 1) the location of this study is limited to a single company in Cepogo copper craft carving, so that the results can not be used to generalize the study of transformational leadership style in Copper Carved Cluster in Boyolali; 2) the number of the respondents is quite small, i.e. 30 respondents, so that the data obtained do not describe the general conditions of employees on Copper Carved Cluster in Boyolali; and 3) information provided by respondents in the questionnaire may be bias, and they do not show the actual condition of the respondents.

\section{Conclusion and Suggestions}

Some of the conclusions of this research are 1) there is a positive and significant effect between transformational leadership style variable to variable of employee empowerment. It is reflected on the significance value of 0.000 which indicates a value of less than 0.05 so that the regression model is feasible to predict the effect of transformational leadership style variable to employee empowerment variable; 2 ) there is a positive and significant effect between transformational leadership style variable to employee performance variable. It is reflected on the significance value of 0.029 , which indicates a value of less than 0.05 , so that the regression model is feasible to predict the effect of transformational leadership style variable to employee performance variable; 3 ) there is a positive and significant influence between the variables of employee empowerment on employee performance variables. This is reflected on the significance value of 0.031 , which indicates a value of less than 0.05 so that the regression model is feasible to predict the effect of employee empowerment variable to employee performance variable; 4) organizational commitment variable is a mediating variable that relates the associations between variables of transformational leadership style and employee performance variables, or in other word, the relationship of transformational leadership style variable to variable of employee performance does not have a direct relationship; 5) employee empowerment variables are mediating variable relating variables of transformational leadership style and employee performance variables, or in other words, the relationship of transformational leadership style variable to variable employee performance does not have a direct relationship; and 6) organizational commitment variable is a mediating variable relating the associations between variables employee empowerment and employee performance variables, or in other words, the relationship of employee empowerment variable to variable employee performance is indirect relationship

Based on the conclusions above, the advices given are 1) transformational leadership style that is applied is still weak and needs to be improved, especially those regarding with notification to the employee's vision and mission, the involvement of employees in decision-making and award from the superiors when the employee works well. Therefore, it is necessary to encourage higher ideals and morals by giving inspiring motivation, stimulation and attention to employees; 2) empowerment of employees in terms of giving them responsibility and authority is still weak. This should be enhanced by providing the opportunity for employee to explore ideas, initiative and to conduct training for the betterment of employee performance; 3 ) the commitment of employees does not fully reflect employee loyalty. Existing rules need to be informed to employees, personal values which are in line with the rules of the company need to be fostered to enhance a sense of belonging; 
and 4) the employee's performance is still weak, especially on the number of defective products and the inability to fulfill the target required by the company. It is suggested that the company needs to improve the skills of employees with training and incentives, as long as target is reached.

\section{References}

Bycio, P., Allen, J. S. \& Hackett, R. D. (1995). Further Assesment of Bass's (1985) Conceptualization on Transactional and Transformational Leadership. Journal of Applied Psychology, 80(4), 468-478.

Chaudron, S. (2005). Creat an Empowering Environment. Personal Journal, 3, 28-37.

Cooper, D. R. \& Emory, C. W. (1996). Business Research Methods. Translated by Ellen Gunawan and Imam Nurmawan, 5th ed. Erlangga. Jakarta.

Dessler, G. (2006). Personal Management, Translated by Agus Dharma, 6 th ed. Erlangga. Jakarta

Handoko, H. \& Tjiptono, F. (2000). Transformational Leadership and Empowerment JEBI. September.

Haryanto, T. (2002). Relevancy of Transformational Leadership to Overcome The Multidimensional Crisis Usahawan. 11. XXXI. Management Institute FE UI.

Luthan, F. (1998). Organization Behavior (Bahasa Indonesia Edition), Prenhallindo, Jakarta.

Khan, S. (2004). The Key to Being a Leader Company: Empowerment. Journal Personality and Participation, Jan/Feb, 44-50.

Keller, R. T. (1992). Transformational Leadership and The Performance of Research and Development Project Groups. Journal of Management, 18, 489-501.

Muchiri, M. K. (2002). The Effect of Leadership Style on Organizational Citizenship Behavior and Commitment: The Case of Railway Corporation. Gadjah Mada Journal of Business, 3(2). MM UGM. Yogyakarta.

Purwanto \& Adisubroto. (2001). Relationship Between Transformational and Transactional Leadership Styles on Organization Commitment. Jurnal Sosiohumanika, 21(1).

Robbins, S. (1996). Organization Behavior: Concept, Controversi and Application (Bahasa Indonesia Edition). Prenhallindo. Jakarta.

Schappe, W. (2001). The Influence of Job Satisfaction, Organizational Commitment, and Fairness Perception on Organizational Citizenship Behavior. Journal of Psychology, 20, 245-260.

Thoha, M. (1995). Leadership in Management. PT.Raja Grafindo Persada. Jakarta.

Tuomi, I. (1999). Corporate Knowledge: Theory and Practice of Intelligent Organizations, Helsinki: Metaxis

Yukl, G. A. (2009). Leadership in Organization (Bahasa Indonesia Edition). Indeks Jakarta. 